\title{
Pengaruh Ability Dan Minat Terhadap Locus Of Control Pegawai Pada PT. Jasa Marga Persero Tbk Cabang Belmera Medan
}

\author{
The Influence Of Ability And Interest To Locus Of Control Employees At PT. Jasa Marga Persero \\ Tbk Belmera Medan Branch
}

Nahar Maganda Saragih

Fakultas Ekonomi dan Bisnis, Program Studi Manajemen, Universitas Potensi Utama, Jl. K.L.Yos Sudarso, Tj. Mulia, Medan Deli, Kota Medan-20241 Telp: (061) 6640525 e-mail: naharmagandasaragih@gmail.com

\begin{abstract}
ABSTRAK
Menghadapi situasi arus globalisasi tiap-tiap organisasi diharuskan untuk selalu dapat menaikkan tingkat kinerja bisnisnya dengan sistem manajemen yang qualified. Bentuk dari upaya-upaya yang dijalankan guna mewujudkan hal tersebut adalah dengan menggunakan jasa-jasa pekerja seminimal-minimalnya dengan tingkat kemampuan baik secara softskill maupun hardskill guna memperoleh output maksimal dan dapat mengikuti apa yang direncanakan organisasi. Sebagaimana diketahui bahwa pekerja atau sumber daya manusia memiliki peran penting dalam organisasi, sebab lewat tangan sumber daya manusia persaingan bisnis dapat berjalan sebagaimana mestinya. Competitive strength hanya berasal dari sumber daya yang berqualified, maka kondisi ini mengharuskan organisasi untuk dapat memonitoring segala jenis aspek yang berguna dalam mendorong kemampuan dan minat para pegawainya untuk dapat meningkatkan locus of control pada masing-masing pegawainya. Adapun pada penelitian yang dilaksanakan ini jumlah yang menjadi populasi yaitu sebanyak 176 pegawai dan dirampingkan menjadi sampel sebanyak 122. Metode yang digunakan dalammenganalisis yaitu regresi linier berganda. Kesimpulan akhir yang diperoleh dalam penelitian yaitu baik secara parsial dan simultan ability dan minat berpengaruh positif dan signifikan terhadap locus of control. Dengan koefisien determinasi sebesar $56 \%$ peran ability dan minat mampu mempengaruhi locus of control.
\end{abstract}

Kata Kunci : Ability, Minat dan Locus of Control

\section{ABSTRACT}

Facing the current situation of globalization, each organization is required to always be able to increase the level of its business performance with a qualified management system. The form of the efforts carried out to achieve this is to use the services of workers with a minimum level of ability, both soft skills and hard skills in order to obtain maximum output and be able to follow what is planned by the organization. As it is known that workers or human resources have an important role in the organization, because through the hands of human resources business competition can run as it should. Competitive strength only comes from qualified resources, so this condition requires the organization to be able to monitor all types of aspects that are useful in encouraging the abilities and interests of its employees to be able to increase the locus of control in each of its employees. As for the research carried out, the number of the population as many as 176 emp loyees and downsized into a sample of 122. The method used in the analysis is multiple linear regression. The final conclusion obtained in the study is that both partially and simultaneously ability and interest have a positive and significant effect on locus of control. With a coefficient of determination of $56 \%$ the role of ability and interest is able to influence the locus of control

Keywords : Ability, Interest and Locus of Control

Info Artikel :

Disubmit: 12 November 2021

Direview: 17 Desember 2021

Diterima :19 Januari 2022

Copyright () 2022 - Journal UPU. All rights reserved. 


\section{PENDAHULUAN}

Bertambah pesatnya kemajuan keilmuan dan teknologi berdampak kepada individu yang tergolong pada angkatan kerja, secara perlahan-lahan semakin minim skills yang dimiliki. Sebagai tenaga kerja banyak pekerja yang tidak mampu mengikuti perkembangan globalisasi dikarenakan kecanggihan dari sebuah teknologi dan evaluasi-evaluasi organisasi. Isu yang berhubungan dengan tatanan sumber daya manusia guna melahirkan kompetensi mempunyai beberapa unsur yakni talent manajerial dan pembaharuan teknologi. Talent manajerial harus ditambah gina mengejar kemampuan dan kompetensi sumber daya manusia dan pembaharuan teknologi wajib diimplementasikan sebagai unsur dan media dalam mencapai superiority. Cakupan dunia bisnis merupakan sebuah pola aktivitas yang menjadi satu unsur guna melihat perkembangan dari sebuah organisasi, instansi dan lembaga lainnya.

Diluar dari unsur internal dan eksternal, usaha-usaha untuk mendapatkan profitabilitas secara cakap merupakan tujuan dari dijalankannya sebuah ativitas bisnis. Kemajuan usaha dan bisnis pada hari-hari ini semakin melaju cepat yang berdampak pada kegiatan dan aktivitas perusahaan yang diharuskan mampu untuk mengikuti arus. Berkaitan dengan itu, banyak keputusan-keputusan yang harus diambil secara tangkas dan lugas dikarenakan pola aktivitas yang mengharuskan pelaku bisnis mampu menerapkan hal itu. Pelaku bisnis dalam hal ini meliputi pegawai sebagai atributatribut utama perusahaan. Tercapainya rangkaian-rangkaian pola kegiatan aktivitas perusahaan senyawa dengan kemampuan para pegawainya, yang mana pegawai menjadi ujung tombak perusahaan dalam mewujudkan apa yang menjadi cita-cita perusahaan.

Pada dasarnya capaian yang diperoleh pegawai berasal kuat dari kemampuan yang dimiliki pegawai secara pribadi, kemampuan kerja merupakan sebuah hasil dari kerja yang diperoleh pegawai dalam menyelesaikan tugas yang diemban kepadanya yang didasari atas tingkat kecakapan, experience, kedisiplinan. Selain itu dalam kemampuan juga mengandung kestabilan karakter yang berkaitan dengan kemaksimalan baik secara mental maupun fisik. Dimana dalam hal ini kemampuan psikologis yang mencakup pengetahuan dan kemampuan skill. Kemampuankemampuan ini dapat muncul dari lingkungan atau pendidikan yang mumpuni untuk posisi pekerjaan dan keterampilan dalam menyelesaikan persoalan pekerjaan sehari-hari. Kemampuan dibaringi dengan keinginan menjadi satu kesatuan yang berkorelasi dalam menumbuhkan kepercayaan diri akan kemampuan yang dimiliki secara pribadi, yang mana dalam minat mengandung sebuah perasaan yang suka dan perasaan tertarik terhadap sesuatu atau dengan kata lain sebuah kegiatan yang dijalankan tanpa ada dorongan atau perintah dari orang lain. Pada dasarnya minat merupakan sebuah acception terhadap suatu korelasi antara sesuatu yang berasal dari ekternal dengan diri sendiri, yang mana apabila hubungan tersebut semakin tinggi maka akan berdampak pada tingginya minat seseorang, dan begitupun sebaliknya.

Minat berkembang terhadap sebuah persoalan pada dasarnya dapat membantu pegawai mempelajari sejauh mana korelasi pekerjaan yang diekspektasikan untuk dikerjakan dengan dirinya sendiri sebagai secara individu. Dari sinilah tingkat kepercayaan akan kemampuan diri sendiri meningkat. Perpaduan antara kemampuan dan minat yang dimiliki seseorang mampu meningkatkan kepercayaan dirinya akan kemampuannya mengontrol sebuah peristiwa yang terjadi dalam kehidupannya yang dilewati dengan kemampuan dan minatnya sendiri dan mampu mengendalikan permasalahan-permasalahan yang terjadi dalam dunia kerja. PT Jasa Marga merupakan perusahaan yang bergerak dalam bidang pembangunan dan penyedia jasa pelayanan jalan tol dengan komponen-komponen pekerja dan teknologi yang dituntut tangkas dan lugas dalam pengambilan keputusan. Pada bidang kemampuan dan kecakapan masih banyak permasalahan ditemukan pada beberapa kegiatan yang dilaksanakan, hal ini muncul dikarenakan dalam tiap bidang pekerjaan, para pegawai hanya melakukan penyesuaian secara otodidak dan kurangnya pelatihan sehingga berdampak pada kurang tergalinya kemampuan pada tiap-tiap pegawai. Jika ditelusuri lebih dalam terkait minat yang dipilih, masih banyak ditemukan permasalahan terkait sejauh mana pegawai sudah mengenali apa minat yang secara mendasar ditekuni dan dimiliki tiaptiap pegawai. 
Kondisi ini jelas menjadi hambatan-hambatan yang dapat menimbulkan permasalahan terkait rendahnya kepercayaan diri seorang pegawai dalam mengontrol peristiwa yang terjadi dalam kehidupannya atau dengan kata lain kondisi ini semakin memperburuk locus of control pada pegawai. Locus of control sendiri dapat tertanam pada pegawai dengan kemampuan yang terus dipupuk dan minat yang semakin jelas. Merujuk terhadap sebuah keyakinan bahwa individu mampu mengontrol sebuah kejadian kehidupan yang dilandasi dari kemampuan personalnya yang dapat dibentuk melalui kemampuan-kemampuan yang dilewati dengan pengalaman. Pengalaman dapat terbentuk melalui proses-proses yang dilewati dari tiap bidang-bidang pekerjaan seperti penyelesaian dalam tiap persoalan dalam bidang kerja. Kemampuan dalam menyelesaikan permasalahan tadi dapat dilalui lewat pelatihan-pelatihan yang diterima oleh individu. Dengan pelatihan yang minim ditambah dengan penyelesaian pekerjaan yang otodidak maka dapat diindikasikan membuat pegawai rentan dalam meningkatkan locus of control dalam dirinya.

Pada dasarnya pada semua aspek kehidupan, contohnya dalam hal menghadapi persoalan tiap individu mempunyai respon dan metode penyelesaian yang tidak sama, begitu juga jika dihadapkan pada individu lain yang juga memiliki sikap dan metode penyelesaian yang berbeda-beda. Namun pada dasarnya semua kemampuan baik itu kemampuan yang berdampak pada hal kecil maupun besar akan dapat menimbulkan locus of control yang meningkat. Dan sebaliknya apabila kemampuan dalam menyelesaikan pekerjaan dan persoalan rendah, maka akan diikuti dengan locus of control yang juga rendah. Pada teori locus of control diterangkan bahwa sikap dan perilaku pegawai pada sebuah perkara akan difaktori oleh locus of control yang mana locus of control juga merupakan persepsi bahwa semua output yang diperoleh baik maupun tidak baik dikarenakan sikap yang bersumber dari capacity dan unsur-unsur yang ada pada masing-masing individu.

Dalam melengkapi terciptanya peningkatan locus of control diperlukan adanya pemahaman terkait konsep minat yang dimiliki masing-masing individu atau pegawai dalam menjalankan apa yang dikerjakan nya. Mengenali dan memahami minat merupakan unsur-unsur penting sebagai upaya dalam spesifikasi bidang pekerjaan. Itulah mengapa pada awal rekrutmen bidang peminatan seharusnya dijalankan oleh perusahaan. Banyak pegawai yang merasa siklus hidupnya terlalui secara monoton dan tidak mempunya gejolak yang penting. Faktor utamanya adalah dikarenakan pegawai tidak menjalankan kesehariannya sesuai dengan minat yang tertanam dalam dirinya dalam mengambil bidang profesi yang dijalaninya. Kondisi ini jelas akan berdampak pada locus of control karena situasi ini dapat menjadi pengganjal dan menjadi penghalang seseorang dalam mencapai tujuan nya secara maksimal. Melalui tes yang seharusnya dilakukan diawal rekrutmen terkait bakat dan minat calon pegawai, perusahaan dapat mengetahui sejauh mana potensi dan minat serta kekurangan dan kelebihan calon pegawai. Kurangnya penelusuran yang dilakukan perusahaan terkait minat pegawainya menyebabkan rendahnya locus of control yang tumbuh pada diri pegawai, tes minat tidak dilakukan secara continuously dan consistent sehingga berdampak pada rendahnya locus of control dan tidak dapat memberikan nilai atau value yang lebih sehingga tidak mampu mendorong aktivitas professional pegawai. Sebab minat yang jelas dan diberi pelatihan secara terus-menerus maka akan memiliki dampak, yang mana minat pada dasarnya merupakan sebuah hobi, yang apabila dijalankan dengan minat yang sesuai, yang tadinya hobi maka akan menjadi kegiatan professional.

Kemampuan dan minat menjadi dua faktor penting dalam menumbuhkan locus of control, dua faktor penting ini yang tidak diterapkan dengan baik oleh perusahaan sehingga menjadi akar penyebab dari rendahnya locus of control yang dimiliki oleh tiap-tiap pegawai. Secara keseluruhan pegawai menjadikan kegagalan yang terjadi bersumber dari faktor eksternal, dikarenakan kurangnya pelatihan dan tidak adanya pelaksanaan tes minat menyebabkan pegawai tidak memahami tingkat ability dan jenis minat yang dimiliki secara individu. Dapat diketahui bahwa apabila seorang pegawai mempunyai locus of control yang tinggi dalam bidang pekerjaan yang dijalaninya, jelas dapat melahirkan motivasi diri agar bekerja lebih giat dalam bekerja sebab locus of control tersebut menggambarkan feeling pegawai pada sesuatu yang dilaksanakan dan tercapainya target yang dicita-citakan. Begitupun sebaliknya, apabila locus of control pegawai rendah, maka akan berdampak pada kemunduran dalam gairah dan keinginan untuk mengimplementasikan potensi diri sebaik mungkin. 


\section{A. Rumusan Masalah}

1) Apakah ability secara parsial berpengaruh positif dan signifikan terhadap locus of control pegawai di PT. Jasa Marga Persero Tbk Cabang Belmera Medan?

2) Apakah ability secara parsial tidak berpengaruh positif dan signifikan terhadap locus of control pegawai di PT. Jasa Marga Persero Tbk Cabang Belmera Medan?

3) Apakah minat secara parsial berpengaruh secara positif dan signifikan terhadap locus of control pegawai di PT. Jasa Marga Persero Tbk Cabang Belmera Medan?

4) Apakah minat secara parsial tidak berpengaruh secara positif dan signifikan terhadap locus of control pegawai di PT. Jasa Marga Persero Tbk Cabang Belmera Medan?

5) Apakah ability dan minat secara simultan berpengaruh secara positif dan signifikan terhadap locus of control pegawai di PT. Jasa Marga Persero Tbk Cabang Belmera Medan?

6) Apakah ability dan minat secara simultan tidak berpengaruh secara positif dan signifikan terhadap locus of control pegawai di PT. Jasa Marga Persero Tbk Cabang Belmera Medan?

\section{B. Tujuan Penelitian}

Penelitian ini bertujuan untuk:

1) Bertujuan agar dapat melihat dan mengetahui bagaimana peran ability dapat mempengaruhi locus of control pegawai di PT. Jasa Marga Persero Tbk Cabang Belmera Medan

2) Bertujuan agar dapat melihat dan mengetahui bagaimana peran minat dapat mempengaruhi locus of control pegawai di PT. Jasa Marga Persero Tbk Cabang Belmera Medan

3) Bertujuan agar dapat melihat dan mengetahui bagaimana peran ability dan minat dapat mempengaruhi locus of control pegawai di PT. Jasa Marga Persero Tbk Cabang Belmera Medan

\section{LANDASAN TEORI}

A. Ability

\section{1) Pengertian Ability}

Ability atau yang biasa disebut dengan kemampuan kerja merupakan sebuah output kerja yang diperoleh individu saat proses pelaksanaan job yang diemban kepadanya dan dilandasi oleh kecekatan, experience, seriousness serta kedisiplinan. Sementara dalam makna serupa yang dikemukakan oleh Kreitner (2015) mendefinisikan bahwa kemampuan kerja merupakan sebuah identitas yang netral dan berkorelasi pada kecakapan fisik dan psikologis individu secara maksimal.

Dalam teknisnya kemampuan digolongkan kepada beberapa kelompok yang tersusun dari potential ability atau yang biasa disebut dengan istilah umum yaitu IQ dan pengetahuan serta kemampuan. Dengan kata lain apabila seseorang ingin memiliki potential ability dapat didorong dengan sistem pendidikan yang matang guna memaksimalkan beban kerja sehari-hari. Dengan adanya dorongan ini maka besar potensi pegawai dalam mencapai prestasi dan tujuan yang ditetapkan. Untuk faktor yang kedua yaitu pengetahuan dan kemampuan, merupakan sebuah kapasitas individu guna melaksanakan bermacam pekerjaan dalam sebuah tugas. Selanjutnya kemampuan ini memiliki beberapa bagian yaitu kemampuan secara intelektual yang merupakan kemampuan yang diperlukan guna menjalankan bermacam kegiatan dalam ranah mengambil keputusan, berkalkulasi, dan analisa. Kemampuan ini memang dibuat guna berfungsinya kemampuan individu secara general. Selanjutnya kemampuan secara fisik yang merupakan kemampuan menjalankan pekerjaan yang mengharuskan pelakunya kuat dalam hal secara fisik misalnya seperti ketahanan tubuh, kekuatan tenaga, dan sebagainya. Kondisi ini dperlukan guna individu dapat menjalankan pekerjaannya dengan tubuh prima 
dan kondisi fisik yang kuat sebab dalam pelaksanaannya tubuh merupakan faktor utama dalam individu mampu menyelesaikan pekerjaannya. Yusdi (2016).

Berdasarkan beberapa pemahaman yang telah dipaparkan diatas dapat ditarik kesimpulan bahwa definisi kemampuan adalah karakter yang telah dimiliki seseorang sedari lahir yang disempurnakan dari pembelajaran yang diperoleh dari sebuah pengalaman yang dijalankan yang mana kemampuan tersebut memungkinkan individu dapat mencapai garis finish dengan baik dan sempurna dalam bidang pekerjaannya. Dengan kata lain sekalipun motivasi yang bertumpah diberikan kepada pegawai akan tetapi pegawai tersebut secara mendasar tidak memiliki kemampuan seperti yang diinginkan, maka apa yang dituntut organisasi tetap tidak akan tercapai. Kemampuan ini menjadi bagian keterampilan khusus yang memiliki peran utama dalam menentukan tindakan dan prilaku seseorang dalam bersikap sampai kepada metodenya dalam mengambil sebuah keputusan. Kondisi ini menjadi gambaran mengapa krusialnya kemampuan dalam mendorong dan menyempurnakan pekerjaan yang ditekuni oleh masing-masing individu dalam mengemban sebuah tanggung jawab yang diberikan kepadanya.

\section{2) Indikator Ability}

Dalam menentukan gambaran pengukuran terkait kemampuan, berikut komponenkomponen yang menjadi dasar dalam mengukur hal-hal yang dapat dijadikan ukuran dalam menentukan kemampuan yang dipaparkan oleh Robbins (2016) yaitu sebagai betikut:

a) Kemampuan Intelektual: Kemampuan intelektual ini terdiri dari beberapa unsur penting yang dikelompokkan menjadi beberapa bagian yang dimulai dari numerical intelligence adalah kecerdasan yang secara umum dapat dilihat dari kemampuan seseorang dalam ranah hitung menghitung angka dengan tingkat kecepatan dan ketepatan yang tinggi. Kedua yaitu verbal understanding yaitu kemampuan individu dalam memahami hal-hal yang telah didengar dan dibaca yang mana tingginya kemampuan seseorang dalam tingkat pemahaman verbal understanding ini dapat diukur dari bagaimana dengan sekali mendengar penjelasan dan sekali membaca konteks penting, individu tersebut sudah mampu memahami dengan seksama. Kemudian kemampuan intelektual yang ketiga yaitu perceptual speed yang mana perceptual speed ini merupakan kemampuan individu dalam mengenali secara visual baik itu visual sama ataupun mirip identik. Keempat yaitu inductive reasoning penalaran yang terdapat dalam diri seseorang terkait pemahamannya dalam mengetahui sebuah susunan logis di sebuah problem lalu dapat memberikan solusi atau metode penyelesaian yang efektif dan benar. Kelima adalah kemampuan deductive reasoning jenis kemampuan ini merupakan kemampuan seseorang dalam menggunakan logika dan memberikan penilaian impilkasi dari sebuah diskusi atau perdebatan, pada umumnya seseorang dengan kemampuan ini mampu dengan tangkas dalam memberikan sanggahan dan perlawanan terhadap lawan bicaranya dan memberikan penjelasan kongkrit terhadap sebuah persoalan yang diperdebatkan. Keenam yaitu space visualization tingkat kemampuan yang dimiliki seseorang yang berkaitan dengan imajinasinya. Seseorang yang memiliki kemampuan ini umumnya mampu menggambarkan sebuah objek dalam pikiran nya secara mendalam, dan memiliki kemampuan dalam mengimajinasikan sebuah konsep yang tersusun dari pada sebuah ruangan ataupun benda lainnya. Kemampuan yang terakhir yaitu memory, kemampuan ini merupakan kemampuan seseorang dalam memblur dan menginat hal-hal yang telah terjadi dimasa lampau dalam hidupnya.

b) Kemampuan Fisik: Kemampuan fisik terbagi menjadi beberapa bagian kelompok yang tediri dari yaitu pertama dynamic strength kekuatan ini merupakan ability yang dapat digunakan otot dengan kurun waktu secara terus-menerus dan dalam tempo waktu yang lama, untuk mengukur kemampuan ini seseorang dapat dilihat dari kedinamisan tubuh nya. Lalu kedua yaitu body strength yang mana kekuatan ini merupakan kekuatan otot tubuh dan handal dalam menjalankan kegiatankegiatan berat yang diberikan oleh perusahaan. Ketiga yaitu verb power selain 
dimiliki oleh kemampuan intelektula, pada kemampuan fisik pun memerlukan kekuatan secara verbal yang mana kekuatan ini digunakan untuk objek-objek yang bersumber dari luar. Urutan lainnya terdapat static strength, extent flexibility, dynamic dexterity, body coordination, balance dan Stamina semua unsur-unsur yang terdapat pada kekuatan fisik ini merupakan kekuatan yang sangat diperlukan dalam menghadapi bidang pekerjaan yang menuntun dominan menggunakan kekuatan fisik, meskipun demikian pada pekerjaan yang memerlukan penalaran juga diperlukan meskipun tidak setinggi pekerjaan fisik.

\section{B. Minat}

\section{1) Pengertian Minat}

Minat merupakan fusion antara keinginan dengan kehendak yang bisa dikembangkan, Sunendar menambahkan bahwa ada 3 unsur pokok yang menjadi batasan dalam minat yaitu sebuah perilaku yang bisa mengikat konsentrasi individu focus kesatu objek dengan pilihan yang selektif. Kemudian yang kedua yaitu sebuah feeling akan kegiatan untuk seseorang yang dianggap sangat penting dan yang terakhir yaitu sesuatu yang termasuk dari bentuk dorongan atau kematangan yang menuju perilaku kea rah satu tujuan yang diinginkan atau yang direncanakan Sunendar (2016).

Minat yaitu sebuah kecenderungan yang konsisten untuk memberikan attention dan mengenang aktivitas yang telah dilalui maka dari itu pada dasarnya minat dapat dilihat dari unsur attention, enjoyment, favorite dan satisfaction sebagai pendorong untuk perilaku dan sikap individu Hilgad (2018).

Dari beberapa pendapat yang telah dikemukakan oleh para ahli dapat diambil kesimpulan bahwa minat adalah sejenis unsur dari psikis yang berfungsi sebagai pendorong perilaku manusia dalam mencapai apa yang ditujukannya. Individu yang mempunya minat pada sebuah objek akan mengkontribusikan pusat perhatian dan fokusnya terhadap sesuatu yang iya minati yang mana apabila seseorang telah memiliki minat terhadap sebuah objek maka dalam melaksanakan apapun yang berkaitan dengan objek tersebut maka individu itu akan sangat mudah dan bahagia dalam menjalaninya. Maka dari itu rendah atau tingginya tingkat perhatian seseorang terhadap sebuah objek dipengaruhi oleh rendah tingginya minat yang dimiliki individu tersebut.

\section{2) Pengukuran Minat}

Dalam menentukan pengukuran terhadap seseorang yang memiliki minat dapat siukur menjadi beberapa bagian seperti yang dikemukakan oleh Safari (2017) yakni:

1) Perasaan Senang

Akan timbul kebahagiaan atau kesenangan saat pelakunya menjalani minat yang telah iya pilih. Perasaan senang ini menimbulkan banyak sekali alternative-alternativ dikarenakan seseorang yang sudah memiliki minat terhadap sesuatu akan terus mengupayakan keberhasilan dari minat yang ditekuninya. Sekalipun muncul kendala-kendala maka individu tersebut akan tetap memiliki cara atau jalan keluar untuk menemukan solusi dari tiap permasalahan yang dihadapinya.

2) Ketertarikan

Seseorang yang memiliki minat terhadap sebuah objek akan tetap memilih sebuah minat yang dipilihnya, meskipun banyak pilihan yang lebih baik dan beragam serta ekonomis diluar minatnya, hal ini dipicu dari ketertarikan yang tidak bisa berubah.

3) Perhatian

Individu dengan tingkat minat yang tinggi akan memfokuskan dirinya pada sebuah objek dengan tingkat focus yang tinggi, sehingga seringkali individu seperti ini memperhatikan segala hal-hal yang berkaitan dengan bidang peminatan yang dimilikinya. Instensitas yang tajam dan pehatian yang tinggi ini muncul akibat efek dari ketertarikannya yang tinggi sehingga individu ini sangat memfokuskan perhatiannya.

4) Keterlibatan 
Dengan adanya perasaan yang menyenangkan, ketertarikan yang tinggi serta kefokusan akan membuat seseorang akan terlibat pada hal yang diminatinya.

\section{Locus of Control}

1) Definisi Locus of Control

Pengendalian atau locus of control adalah tingkatan seberapa jauh individu mengekpektasikan bahwa kekuatan atau hasil dari perbuatannya bergantung pada penilaian pribadi. Pada umumnya seseorang yang memiliki perilaku locus of control yang tinggi akan menganggap bahwa segala yang terjadi dalam proses kehidupan nya bersumber dari dirinya sendiri dan solusi yang dibuat harus berasal dari dirinya sendiri Allen (2017).

Sedangkan menurut Smet (2015) locus of control yaitu seseorang berkeyakinan bahwa dirinya sendirilah yang menjadi penyebab dari nasibnya sendiri. Hal ini sesuai dengan imbalan yang diterimanya dan sesuai dengan peristiwa-peristiwa yang dialaminya. Atas dasar inilah seseorang yang memiliki locus of control yang tinggi akan berprilaku sangat objektif di dalam kesehariannya.

Dari kumpulan teori diatas dapat disimpulkan bahwa pada dasarnya locus of control merupakan keyakinan seseorang terhadap sebuah konsekuensi dari perbuatan yang dilakukan nya pada masa lampau dan dari konsekuensi-konsekuensi inilah individu ini beranggapan bahwa kendali atas hidup dan pilihan bergantung akan kendali dari dirinya sendiri.

\section{2) Pengukuran Locus of Control}

Terdapat beberapa pengukuran atau indikator dalam mengukur locus of control yang dipaparkan oleh Sanjiwani (2016)

1) Pengukuran Ekternal

Pengukuran locus of control pada tahap ekternal meliputi peluang dan kekuatan dari luar. Maksud dari pengukuran ini adalah seseorang berharap pengendalian yang terjadi dalam hidupnya terjadi akibat dari dorongan ekternal atau faktor dari luar seperti misalnya peluang, yang mana peluang dalam hal ini bersumber dari kemampuan orang lain atau kesempatan yang diperolehnya dari luar kendalinya. Individu dengan kepribadian seperti ini cendrung mengharapkan bantuan dari orang lain serta pengharapan dari sumber-sumber diluar dari dirinya.

2) Pengukuran Internal

Locus of control internal terbagi menjadi dua kelompok yaitu ability dan own doing yang mana pribadi dengan locus of control internal berkonsep pada pengharapan terhadap kemampuan dan hasil kerja yang diperoleh dari dirinya sendiri. Seseorang dengan locus of control internal juga murni mengandalkan kemampuan dan upayaupayanya sendiri sehingga iya bertanggung jawab pada dirinya sendiri dalam semua aspek yang terjadi.

D. Kerangka Berfikir

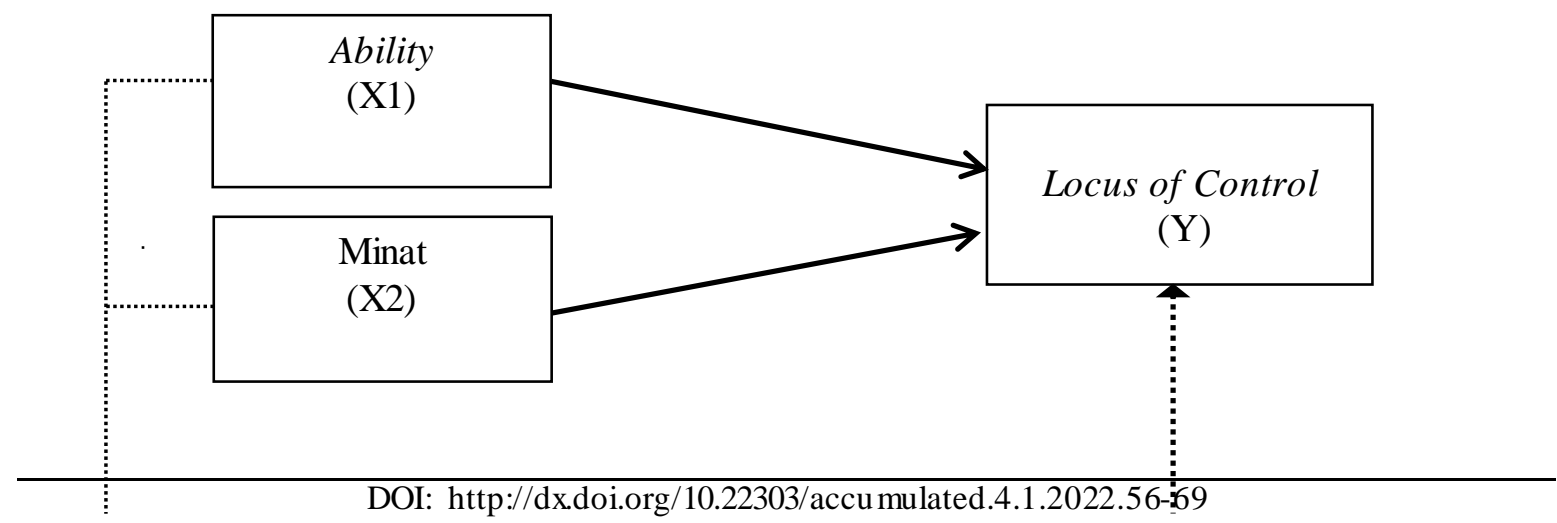




\section{E. Hipotesis}

1) Hipotesis 1: Terdapat pengaruh positif dan juga signifikan antara variabel ability dengan locus of control

2) Hipotesis 2: Tidak terdapat pengaruh positif dan juga signifikan antara variabel ability dengan locus of control

3) Hipotesis 3: Terdapat pengaruh positif dan juga signifikan antara variabel minat dengan locus of control

4) Hipotesis 4: Tidak terdapat pengaruh positif dan juga signifikan antara variabel minat dengan locus of control

5) Hipotesis 5: Terdapat pengaruh positif dan juga signifikan antara variabel ability dan variabel minat secara bersama-sama minat dengan locus of control

6) Hipotesis 6: Tidak terdapat pengaruh positif dan juga signifikan antara variabel ability dan variabel minat secara bersama-sama minat dengan locus of control

\section{METODOLOGI PENELITIAN}

\section{A. Jenis dan Sifat Penelitian}

Jenis yang digunakan dalam penelitian ini yaitu jenis penelitian yang mampu menggambarkan penelitian secara kuantitatif yang disusun secara sistematis berdasarkan pokok permasalahan dan peristiwa. Jenis penelitian ini digunakan dengan tujuan untuk dapat memberikan gambaran yang valid terhadap outpun yang akan dihasilkan.

\section{B. Populasi dan Sampel}

1) Populasi

Pada penelitian yang dilakukan di PT. Jasa Marga Persero Tbk Cabang Belmera medan ini digunakan populasi sebanyak 176.

2) Sampel

Untuk menghasilkan penelitian yang efektif dan tepat peneliti mengambil sampel guna memangkas waktu dan tenaga serta biaya dengan menggunakan persamaan slovin sehingga menghasilkan jumlah sampel dari 176 menjadi 122 pegawai, yang mana sampel ini sudah dapat mewakilkan dari masing-masing divisi yang diteliti.

\section{Skala Dalam Pengukuran}

Pengukuran dilakukan untuk memberikan patokan terhadap opini-opini yang diberikan para pengisi kuesioner dalam memberikan pendapatnya terkait pernyataan-pernyataan yang diberikan. Lewat angka-angka yang ditetapkan ini pegawai dapat mempolakan pendapat nya lewat skala likert yang diberikan. Skala likert ini memiliki makna pada masing-masing angkanya dan peneliti meneletakkan angka dengan skor 1 untuk memberikan penilaian bahwa pegawai "sangat tidak setuju" terhadap pernyataan yang diberikan, lalu skor 2 untuk memberikan penilaian bahwa pegawai "tidak setuju" terhadap pernyataan yang diberikan. Kemudian skor 3 untuk memberikan penilaian bahwa pegawai "setuju" terhadap pernyataan yang diberikan dan terakhir skor 4 untuk memberikan penilaian bahwa pegawai "sangat setuju" terhadap pernyataan yang diberikan. Penggunaan skor-skor ini dipergunakan untuk membantu peneliti dalam menghasilkan kesimpulan secara kuantitatif.

\section{Sumber-Sumber Data}

\section{1) Data Fundamental}


Secara umum data fundamental disebut juga dengan data primer yang mana data ini diperoleh dari sumber utama dan dapat dijadikan data dalam menentukan akar permasalahan pada penelitian dan data ini diperoleh dari pra survey, dan data-data penting lainnya yang dapat digunakan dalam menemukan permasalahan pada penelitian serta datadata yang terintegrasi dengan penelitian baik secara langsung maupun tidak langsung.

2) Data Penunjang

Dalam hal ini data penunjang digunakan dari luar objek penelitian namun dapat menyokong hasil dari penelitian, selain itu dapat digunakan untuk memberikan landasanlandasan yang kuat dalam membuat hipotesa seperti misalnya teori yang berasal dari buku, hasil kesimpulan lain dari penelitian yang sama yang bersumber dari jurnal-jurnal peneltian terdahulu. Dengan kata lain data penunjang atau data sekunder ini digunakan untuk membantu peneliti dalam mengembangkan dan menguatkan hal-hal yang lewat teori dan jurnal yang mendukung.

\section{E. Metode Agrerasi Data}

Dalam menemukan fenomena permasalahan dan data-data yang menguatkan, diperlukan beberapa alternativ yang diperlukan antara lain yaitu:

a) Metode Interviu

Interviu atau wawancara digunakan untuk mengetahui secara langsung terkait informasiinformasi yang diperlukan dalam penelitian, yang mana dalam prosesnya peneliti berusaha untuk mendapatkan rangkaian informasi krusial yang berkaitan dengan fenomena permasalahan yang ada pada objek penelitian. Hal ini dilakukan dengan cara memberikan pertanyaan-pertanyaan yang relevan seputar permasalahan yang terjadi dan data yang berkaitan dengan permasalahan tersebut pada pihak PT Jasa Marga persero Tbk Cabang Belmera Medan

\section{b) Metode Pengarsipan}

Pengarsipan atau dengan kata lain yaitu metode yang mempelajari isi-isi dari dokumentasi yang tersedia yang dilakukan guna mempelajari dan menganalisa secara mendalam terkait permasalahan pada penelitian. Metode ini dilakukan mengingat tidak semua informasi dapat diperoleh dari interviu, itulah kenapa diperlukan lagi peneliti mempelajarinya lewat pengarsipan atau pengumpulan data agar informasi yang diperoleh dapat disusun dengan lengkap.

c) Penyebaran Kuisioner

Setelah sebelumnya peneliti menentukan skor pada tiap masing-masing angka dengan ketentuan nya masing-masing, hasil dari pengolahan itulah yang akan menjadi output pada penelitian. Penyebaran kuesioner dilakukan untuk mengetahui bagaimana opini dan pendapat dari masing-masing pegawai, hal ini sangat perlu dilakukan menginat jenis penelitian ini merupakan penelitian kuantitatif yang harus menggambarkan penelitian secara mendalam. Secara teknisnya penyebaran kuesioner dilakukan dengan menyebarkan kumpulan pernyataan-pernyataan kepada sampel yang telah ditentukan sebelumnya kepada 122 pegawai

\section{HASIL DAN PEMBAHASAN}

\section{A. Output Pengujian Asumsi Klasik}

\section{1) Normalitas}

Pengujian normalitas dilakukan untuk melihat sejauh mana kenormalan data yang diperoleh dari kuesioner sebelumnya yang telah diisi oleh responden. Hasil tersebut dapat dilihat pada tabel 1 berikut ini:

Tabel 1. Output Normalitas 


\begin{tabular}{|ll|r|}
\hline & & $\begin{array}{r}\text { Unstandardized } \\
\text { Predicted Value }\end{array}$ \\
\hline Normal Parameters ${ }^{\mathrm{a}}$ & Mean & 122 \\
& Std. Deviation & 28.9344262 \\
Most Extreme Differences & Absolute & 2.93635328 \\
& Positive & .055 \\
& Negative & .051 \\
Kolmogorov-Smirnov Z & & -.055 \\
Asymp. Sig. (2-tailed) & & .608 \\
\end{tabular}

a. Test distribution is Normal.
Setelah dilakukan

pengujian maka diperoleh hasil dari uji normalitas yaitu sebesar $\quad 0,854$.

Kondisi ini menggambarkan bahwa data sudah terdistribusi secara normal. Kondisi ini diambil berdasarkan ketetapan yang mana dengan nilai sig $>0,05$ maka dapat dibuat kesimpulan data sudah normal. Normalitas merupakan metode krusial yang harus dilalui sebelum melakukan pengolahan data selanjutnya, maka dari itu untuk melengkapi data normalitas menjadi lebih sempurna, peneliti melampirkan hasil uji normalitas secara grafik yang mana secara numerik telah ditampilkan pada tabel 1 dan secara grafik akan ditampilkan pada gambar 1 berikut:

Histogram

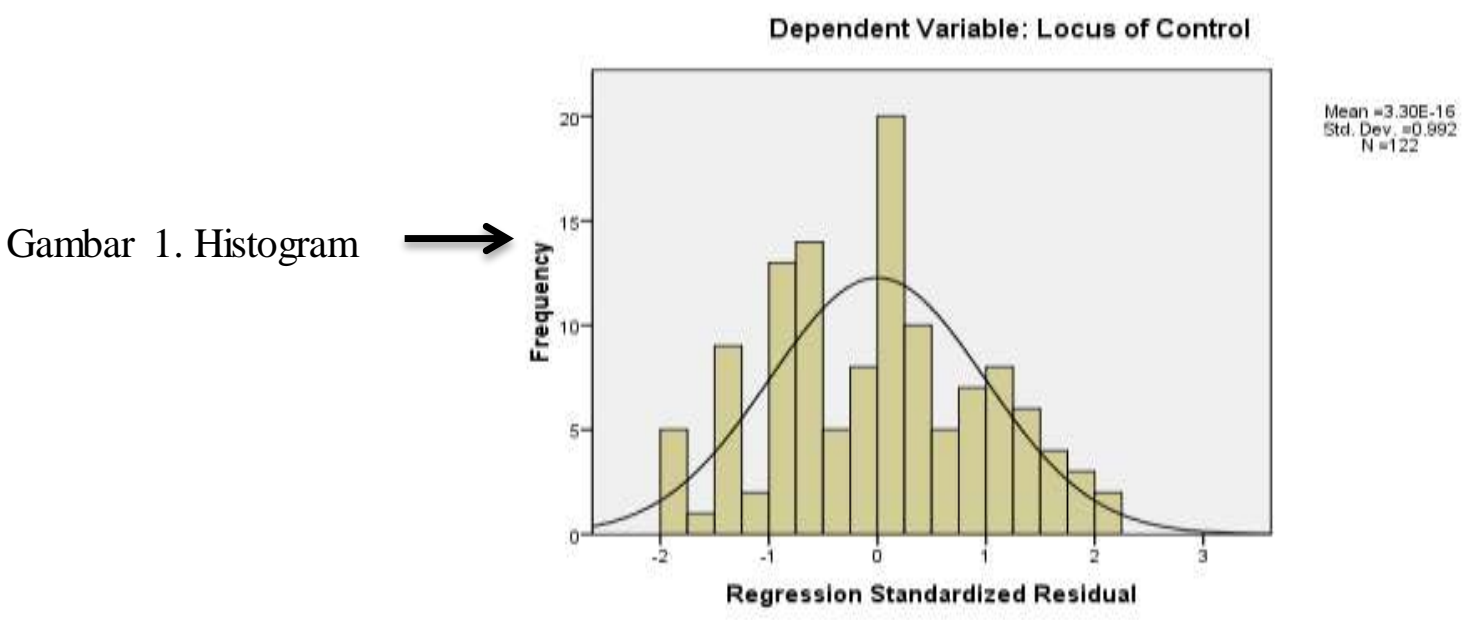

Gambar 2. P-plot

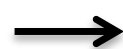

Normal P.P Plot of Regression Standardized Residual

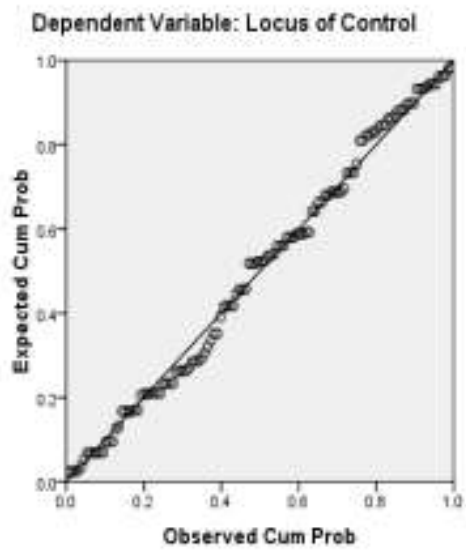


Baik dari grafik histogram dan p-plot menunjukkan bahwa data normal sebab hasil yang diperlihatkan grafik histogram dengan bentuk dari lonceng yang sempurna dan p-plot yang telah membentuk garis diagonal.

\section{2) Heterokedastisitas}

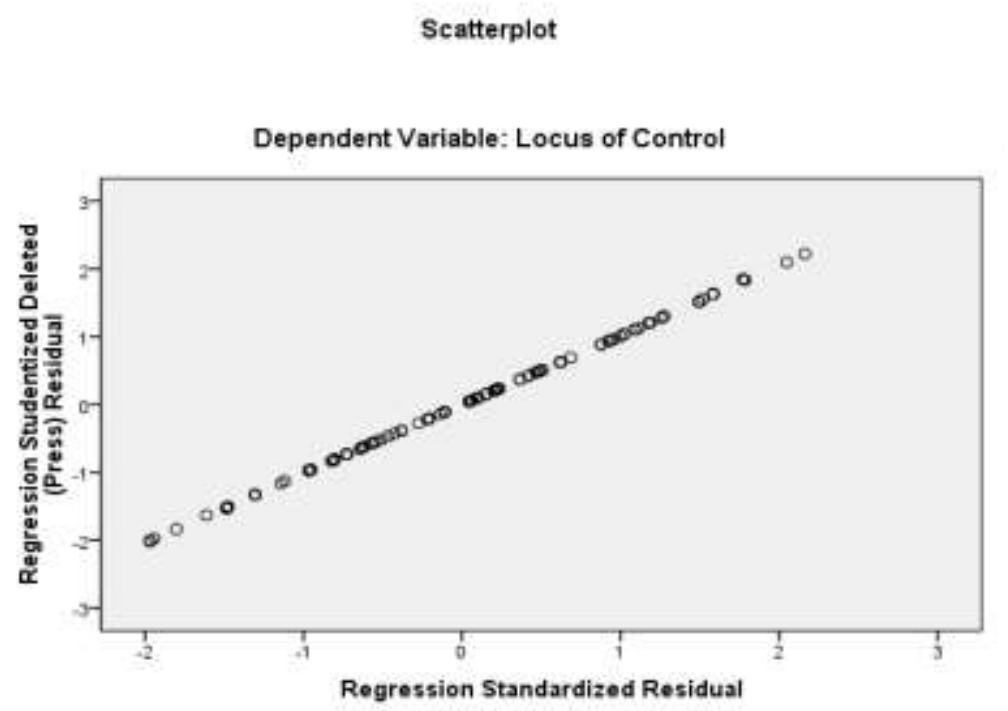

Gambar 3. Heterokedastisitas

Dari pola gambar yang dihasilkan pada uji heterokedastisitas dapat dilihat bahwa data tidak membentuk pola-pola tertentu, maka dapat diambil kesimpulan bahwa tidak adanya terjadi heterokedastisitas pada data yang diteliti.

\section{3) Hasil Pengujian Regresi}

\section{a) Output Pengujian Uji T}

Tabel 2. Output Uji Regresi Berganda

Coefficients $^{\mathrm{a}}$

\begin{tabular}{|c|c|c|c|c|c|}
\hline \multirow{2}{*}{\multicolumn{2}{|c|}{ Model }} & \multicolumn{2}{|c|}{ Unstandardized Coefficients } & \multirow[b]{2}{*}{$\mathrm{t}$} & \multirow[b]{2}{*}{ Sig. } \\
\hline & & B & Std. Error & & \\
\hline \multirow[t]{3}{*}{1} & (Constant) & 4.380 & 2.020 & 2.168 & .032 \\
\hline & Ability & .433 & .061 & 7.145 & .000 \\
\hline & Minat & .439 & .057 & 7.671 & .000 \\
\hline
\end{tabular}

a. Dependent Variable: Locus of Control

Persamaan regresi dapat disusun sebagai berikut:

$\mathrm{Y}=4,380+0,433$ (Ability) $\mathrm{X} 1+0,439$ (Minat) $\mathrm{X} 2+\mathrm{e}$

1. $\beta_{0}=4,380$

Pemaknaan persamaan yaitu: 
Nilai dari konstanta sebesar 4,380. Nilai ini mendefinisikan bahwa dengan diterapkannya variabel ability dan variabel minat maka variabel y akan meningkat sebesar 4,380

2. $\beta_{1}=0,433$

Nilai dari konstanta sebesar 0,433 Nilai ini mendefinisikan bahwa dengan diterapkannya variabel ability maka variabel y akan meningkat sebesar 0,433

3. $\beta_{02}=0,439$

Nilai dari konstanta sebesar 0,439. Nilai ini mendefinisikan bahwa dengan diterapkannya variabel minat maka variabel y akan meningkat sebesar 0,439

\section{b) Output Pengujian Uji F}

Tabel 3. Output Pengujian Uji F

ANOVA $^{\mathrm{b}}$

\begin{tabular}{|c|c|c|c|c|c|c|}
\hline \multicolumn{2}{|c|}{ Model } & \multirow{2}{*}{$\begin{array}{r}\text { Sum of Squares } \\
1043.283\end{array}$} & $d f$ & \multirow{2}{*}{$\frac{\text { Mean Square }}{521.641}$} & \multirow{2}{*}{$\frac{F}{75.317}$} & \multirow{2}{*}{$\begin{array}{r}\text { Sig. } \\
.000^{\mathrm{a}}\end{array}$} \\
\hline 1 & Regression & & 2 & & & \\
\hline & Residual & 824.193 & 119 & 6.926 & & \\
\hline & Total & 1867.475 & 121 & & & \\
\hline
\end{tabular}

a. Predictors: (Constant), Minat, Ability

b. Dependent Variable: Locus of Control

Output pengujian dari hasil pengolahan uji $\mathrm{F}$ dapat dilihat dari nilai sig, dan nilai sig yang diperoleh sebesar 0,000. Maka jika dibandingkan dengan nilai dari ketentuan alpha yang harus lebih kecil, maka hasil dari simultan dapat diterima yaitu kategori nilai sig lebih kecil dari nilai ketentuan alpha.

\section{c. Output Koefisien Determinasi}

Tabel 4. Output Pengujian Koefisien Determinasi

\begin{tabular}{|c|c|c|c|c|}
\hline \multicolumn{5}{|c|}{ Model Summaryb } \\
\hline Model & $\mathrm{R}$ & R Square & $\begin{array}{l}\text { Adjusted R } \\
\text { Square }\end{array}$ & $\begin{array}{c}\text { Std. Error of the } \\
\text { Estimate }\end{array}$ \\
\hline 1 & $.747^{a}$ & .559 & .551 & 2.63173 \\
\hline
\end{tabular}

Output pengujian dari koef determinan yang dihasilkan sebesar 0,551. Hal ini dapat dilihat dari nilai adjusted $\mathrm{R}$ square. Nilai yang diperoleh menggambarkan dari kedua variabel atau seluruh variabel $\mathrm{x}$ (ability dan minat) dalam mempengaruhi variabel ya. Dengan kata lain seberapa besar nilai kontribusi atau dampak yang dimiliki dari seluruh variabel $\mathrm{x}$ terhadap variabel $\mathrm{y}$. Nilai output dapat digunakan untuk melihat sebesar apa efektifitas dari penerapan seluruh variabel x (ability dan minat). Nilai ini dapat digolongkan sangat berdampak pada variabel y, mengingat nilai yang dihasilkan lebih dari 50\%. Dapat disimpulkan bahwa (ability dan minat) merupakan variabel yang kuat dalam mempengarui tinggi rendahnya locus of control.

\section{KESIMPULAN}


1) Output dari nilai konstanta sebesar 0,433 Nilai ini mendefinisikan bahwa dengan diterapkannya variabel ability maka variabel y akan meningkat sebesar 0,433. Berdasarkan angka ini dapat disimpulkan bahwa variabel X1 yaitu ability berpengaruh positif dan signifikan terhadap locus of control maka dari itu hipostes pertama dapat diterima

2) Output dari nilai konstanta sebesar 0,439. Nilai ini mendefinisikan bahwa dengan diterapkannya variabel minat maka variabel y akan meningkat sebesar 0,439. Berdasarkan angka ini dapat disimpulkan bahwa variabel X2 yaitu minat berpengaruh positif dan signifikan terhadap locus of control maka dari itu hipostes ketiga dapat diterima

3) Output dari hasil pengujian simultan sebesar 0,000 maka dari itu dapat dibuat kesimpulan bahwa secara bersama-sama seluruh variabel X (ability dan minat) berpengaruh positif dan signifikan terhadap locus of control maka dari itu hipostes kelima dapat diterima

\section{REFERENSI}

[1] Allen James (2017) Personality Theories, Yogyakarta: Prismasophie

[2] Amalini Fiqih dkk, (2016) Pengaruh Kepuasan Kerja dan Minat Terhadap Locus of Control (Studi Kasus Pada Karyawan Perusahaan Daerah Air Minum PDAM Kota Malang) Jurnal Administrasi Bisnis Vol 35 No 1

[3] Ary Restu Iwan dan Sriathi Anak Ayu Agung (2019) Pengaruh Kemampuan dan Self Efficacy Terhadap Locus of Control (Studi kasus Pada Ramayana Mal Bali) E-Jurnal Manajemen Vol 8 No 1

[4] Atkinson, Hilgar (2018) Pengantar Psikologi, Yogyakarta: Pustaka Belajar

[5] Boeree George (2017) Personality Theories: Melacak Kepribadian Anda Bersama Psikolog Dunia, Jakarta: Pris masophie

[6] Chris Rowley dan Keith Jackson, (2015) Manajemen Sumber Daya Manusia: The Key Concepts, Bandung: PT. Raja Grafindo Persada

[7] Danim Sudarwan (2011) Metode Penelitian Kualitatif dan Kuantitatif, Bandung: Pustaka Setia

[8] DL Wuryaningsih dan Kuswati Rini (2015) Pengaruh Ability dan Motivasi Terhadap Locus Of Control Pada Dosen Fakultas Ekonomi dan Bisnis Universitas Muhammadiyah Surakarta, Vol 6, No 3

[9] Hall Calvin (2016) Teori-teori Psikodinamik, Jakarta: Penerbit Erlangga

[10] Idrus Muhammad (2011) Metode Penelitian Ilmu sosial Pendekatan Kualitatif dan Kuantitatif, Jakarta: Erlangga

[11] J. Meleong Lexy (2014) Metodologi Penelitian Kuantitatif, Surabaya: PT Remaja Rosdakarya

[12] Kreitner Robert, (2015) Perilaku Organisasi: Organizational Behavior Edisi 5 Buku II, Salemba Empat

[13] Nefid, Jeffry S. dkk (2015) Psikologi Abnormal Jakarta: Erlangga

[14] Robbins, P. Stephen (2016) Manajemen Sumber Daya Manusia Jakarta: Salemba Empat

[15] Safari Muhammad (2017) Teori Kepribadian, Jakarta: Gerallmu

[16] Sanjiwani Tirta (2016) Psikologi Kepribadian, Bandung: Salemba Humanika

[17] Schermenharn John R (2015) Manajemen, Yogyakarta: Penerbit Andi

[18] Singarimbun Masri (2015) Metode Penelitian dengan Analisis Survey, Jakarta: Erlangga

[19] Subagyo Joko (2012) Metode Penelitian: Dalam Teori dan Praktek Jakarta: PT Rineka Cipta)

[20] Sugiono (2016) Memahami Penelitian Kualitatif, Jakarta: Alfabeta 
[21] Sujanto (2013) Psikologi Kepribadian, Bandung: Alfabeta

[22] Supratiknya (2015) Mengenal Perilaku Abnormal, Bandung: Kanisisus

[23] Suprihanto John (2015) Manajemen Personalia, Yogyakarta: BPFE.

[24] Sunendar Pribadi (2016) Strategi dan Model Pembelajaran, Jakarta: PT Bumi Aksara.

[25] Tri Cahyono, Bambang (2016) Manajemen Sumberdaya Manusia, Surabaya: Badan Penerbit Ipwi.

[26] Veithzal Rivai (2015) Pengelolaan Sumber Daya Insani, Surakarta: Bumi Aksara.

[27] Yusdi Muhammad, (2016) Prinsip-Prinsip Manajemen Semarang: Rineka Cipta.

[28] Zaitun. H. Bukhari (2015) Manajemen Sumber Daya Manusia, Jakarta: CV. Haji Masagung. 